\title{
Academic Branding and Positioning through University's Website Profile
}

\author{
Thomas Wayne \\ Questbury Research Services \\ Thomas.Wayne@,questbury.com \\ (D0000-0002-7855-8587 \\ Emmanuel Mogaji \\ University of Greenwich \\ e.o.mogaji@greenwich.ac.uk \\ (iD)0000-0003-0544-4842
}

\begin{abstract}
Personal branding is becoming an essential concept for academic staff. They often use their owned media such as social media, blogpost and website to engage with the audience and disseminate their works. This study, however, focuses on the staff profile on the University's website. The web page is a media earned by the staff, by virtue of their employment but owned by the University. The University controls the content of these webpages but allows the academic staff to present themselves based on the stipulated. This study analyzed academic staff profiles across 136 UK Universities. Twenty-eight key sections were identified and further group into five themes of Personal Information, Educational Information, Research Information, Industry Information and Engagement Information. There were instances of incomplete and outdated profile and profile with no photographs. The study contributes to studies on academic branding and higher education marketing. The study highlights the responsibilities of the University to provide the platform and encourage staff to make use of the opportunity to develop and maintain their brand. It offers practical implications for University Managers, Information and Communications Technology, Marketing Communications and Academic Staff on how to develop and manage staff profile.
\end{abstract}

Keywords: Academic Branding, Personal Branding, Branding, Website, Academic Staff, Higher Education

\section{Background}

Personal branding is becoming an essential concept for academic staff as they try to build their reputation, raise awareness about research activities and engage in media activities. The growing interest in the Internet and other digital technologies, transforming the practice of education has also further contributed 
to the need for a personal brand. Duffy \& Pooley (2017) noted that as universities are becoming progressively more market-driven, Academic staff are experiencing a lateral pressure to engage in self-promotional practices, highlighting more reasons to be visible and showcase one's impact through quantifiable metrics (Gandini, 2016; Mogaji, 2019).

Personal branding is also useful and influential in the processes of "going up" promotion and tenure (Johnson \& Eulanda, 2017), it is becoming a crucial promotional device for the pursuit of self-realization (Gandini, 2016). Having a personal distinguishes the staff and enhances their reputation. Personal branding recognizes the conscious and unconscious decisions that are being made (Kalia, et al., 2017), which affect the reputation of the academic staff and the likelihood of engaging in any collaboration or partnership

Previous studies have recognized the role of social media for academics selfbranding, recognizing the relevance of social media around a shared notion of reputation, an investment in social relationships with an expected return (Gandini, 2016), Academic staffs are using social media, including ResearchGate and academia.edu to share and disseminate their work. Using these social media to curation a professional image and the management of social relationships for purposes of professional success and career progression is recognized (Gandini, 2016). However, the University website Profile offers a different approach to this curation.

The profile of academic staff in a University is presented on a web page which is within a website of the University. While the academic staff can curate their social media, to frame it in a way they think will appeal to their audience, this is not possible with a University profile. The content of the webpage is often authorized by the University, to ensure it is consistent, professional, up to date and represents the University brand as much as intended. The University controls the staff's webpage - its content represents the values of the university; if the staff leaves the University, that webpage may be deleted. Importantly as well, it highlights a sense of affiliation and reputation to have a page on the University website.

Even though having a personal brand is significant because it distinguishes individuals academic staff (Kalia, et al., 2017), the personal brand of the academic staff is different from the brand of the University brand (Wayne, et al., 2020), highlight the need to have a balance between how the staff may want to 
communicate their brands but still doing so within the structures of the University. Notwithstanding the arrangement around the ownership of the webpage, the University offers academic staff the platform to communicate and share information about their capability to various stakeholders that may engage with the website.

While many studies have explored academic branding on owned social media, this study focuses explicitly on the earned media for the University staff's branding. The study recognizes that the Universities owns this media, but the staff has earned it under their employment. The explores the nature of the information that UK Universities are making available for their academic staff to shape their brand. The study aims to highlight key themes that have been identified by the Universities as appropriate enough for their staff to showcase their expertise and capabilities.

This study contributes to the understanding of personal branding and positioning from an academic staff point of view, especially on a media they do not own or have much control over. It offers insight into how staff are presenting themselves to the world through their profile as stipulated by their Universities. Besides, it also highlights the responsibilities of the University to provide the platform and encourage staff to make use of the opportunity to develop and maintain their brand. It offers practical implications for University Managers, Information and Communications Technology (ICT), Marketing Communications and Academic Staff on how to develop staff profile and to make the information readily available.

\section{Methodology}

The research methodology used for this study is thematic analysis. Thematic analysis is considered as an inductive generic qualitative approach that "seeks to discover and understand a phenomenon, a process or the perspectives and worldviews of the people involved" (Caelli et al., 2008, p. 3). Braun and Clarke (2006, p. 79) further considered it as "a method for identifying, analyzing and reporting patterns within data". To this extent, patterns within the academic staff's website profile were derived from understanding key themes around their academic branding and positioning.

In 2018-19, there were 271 higher education institutions in the UK according to the Higher Education Statistics Agency (HESA) (HESA, 2019). This list however includes publicly funded universities and other higher education institutions 
(HEIs) in the UK, alternative HE providers (APs) that offer HE courses but do not receive annual public funding, and further education colleges (FECs) in Wales which provide some HE level courses. This study, however, decided to focus on Universities which are guaranteed to have academic staff interested in teaching, research and enterprise. The sampled Universities was therefore limited to 136 Universities in the UK which are members of Universities UK (Universities UK, 2020). This sampling method has been used by previous studies that analyzed websites and prospectus of UK Universities (Mogaji, 2016; Mogaji \& Yoon, 2019).

The study adopts the Availability, Location, Accessibility, Relatability and Actionability (ALARA) Model of Information Search on the website (Mogaji, 2019). The methodology takes up the role of an information searcher and incorporates the idea of netnography and user experience design. The methodology highlights the provision of information for the prospective visitor. It places the responsibility on the website owner, the Universities and academic staff, in this case, to provide information about the staff, their experiences and activities (Mogaji, et al., 2020).

The websites of the 136 Universities in the sample were visited between 20th and 25th January 2020 to identify key themes they were presented on the academic staff's profile. The visit starts from the landing page of the Universities to locate staff profile, often through 'about-us/staff-team' or 'faculty/faculty-profiles'. If this does not yield result, as it was often difficult to identify the right path, a Google search with the name of university and staff profile - 'university of university staff profile' was done to provide a landing page for the staff which are ether grouped Alphabetically or according to Faculty/Department. For each University, five different profile was checked to understand further the different types of headings provided as it was found that some of the staff did not activate/use some of the headings. It also assumed that the University would use the same template/format for their staff's profile; therefore, there was no need for a comparison between layout and content of different profiles within the same University.

Braun and Clarke (2006) noted that thematic analysis involves several choices that should be made explicit about guaranteeing the validity and reliability of the study. Among these is the identification of themes within the data and the "level" at which these themes are to be identified. The themes within the data are identified from the collected list from all the Universities. There were familiarization and 
immersion with the identified themes, Braun and Clarke (2006, p. 87) noted that "immersion usually involves 'repeated reading' of the data and actively reading the data - searching for meanings, patterns and so on". The types of Universities were also taken into considering during the familiarization proves. Art Universities had a different section from Business Universities. Arts Universities had Exhibitions and Filmography sections which did not apply to Business Schools.

Different sections were merged based on how closely related they were. Engagement and impact were merged with External Engagement as that was predominantly used across the Universities. Telephone number, Email and Office Addresses were merged into Contact Details. Likewise, some distinctions and separations were also made with the themes. Knowledge Exchange was separated from Research projects and activities as one tends more towards the Industry while the other was towards theoretical contributions. Research Interest was also separated from Research Project. After the mergers and separations. Media Appearance was also separated from Press Expertise. Newspaper articles may count as Media appearance but Press expertise except the academic staff to be press-ready and be able to comment on Live matters which may require training.

\section{Results}

This study aimed to identify key themes used by UK Universities academic staff on their profile. The analysis and refinement of the themes produced 28 child nodes (sub-themes). After detailed analysis, five parent nodes (main themes) emerged (from 28 child nodes). Personal Information, Educational Information, Research Information, Industry Information and Engagement Information.

A detailed list and description of the themes is provided in Table I below. 
Table 1: The 28 Possible Sections on the University's Academic Staff Profile

\begin{tabular}{|c|c|c|c|}
\hline $\mathrm{S} / \mathrm{N}$ & \multirow{2}{*}{\multicolumn{2}{|c|}{\begin{tabular}{l|l} 
Personal & Name \\
Information &
\end{tabular}}} & Section \\
\hline 1 & & & $\begin{array}{l}\text { This section of the webpage presents the } \\
\text { official name of the academic staff. This } \\
\text { section indicates how academic staff will } \\
\text { want to be addressed. This section is } \\
\text { essential for those who may often be } \\
\text { addressed by the short form of their } \\
\text { names but want the full official name on } \\
\text { their University Profile. }\end{array}$ \\
\hline 2 & & Title & $\begin{array}{l}\text { This section, though often part of the } \\
\text { name, indicates the official title of the } \\
\text { academic staff. PhD holders will mostly } \\
\text { likely have Dr For those with no PhD, } \\
\text { and it is essential to identify if they want } \\
\text { to have a title before their name. }\end{array}$ \\
\hline 3 & & Position/Status & $\begin{array}{l}\text { This section is the designated title of the } \\
\text { staff. This section may not be related to } \\
\text { the title. Lecturer in Advertising is the } \\
\text { position while Dr is the title. }\end{array}$ \\
\hline 4 & & Photograph & $\begin{array}{l}\text { This section is the profile image. It should } \\
\text { be a professionally taken portrait } \\
\text { photography, preferable coloured and } \\
\text { organized by the University for } \\
\text { consistency. In some cases, only the } \\
\text { University can upload or update the } \\
\text { profile picture of the staff profile. }\end{array}$ \\
\hline 5 & & Biography & $\begin{array}{l}\text { The biography is often in the third } \\
\text { person, describing the academic staff. It } \\
\text { provides a summary of the research and } \\
\text { teaching interest, achievements and } \\
\text { contributions. It can also include the year } \\
\text { the staff joined the University, previous } \\
\text { Universities and past experiences. }\end{array}$ \\
\hline 6 & & Contact Details & $\begin{array}{l}\text { This section provides the physical address } \\
\text { of the academic staff on the University }\end{array}$ \\
\hline
\end{tabular}




\begin{tabular}{|c|c|c|c|}
\hline & & & $\begin{array}{l}\text { Campus. It should include the Room } \\
\text { Number, if applicable, telephone number } \\
\text { and email. This contact details can also } \\
\text { include Office Hours. }\end{array}$ \\
\hline 7 & & $\begin{array}{l}\text { Social Media } \\
\text { Account }\end{array}$ & $\begin{array}{l}\text { Social media is becoming an essential } \\
\text { feature for academic staff branding. } \\
\text { Universities now include links to the } \\
\text { staff's social media profile. Specifically, } \\
\text { the Universities are focusing on Twitter } \\
\text { and LinkedIn. The University of Surrey } \\
\text { provided a link to Facebook. The } \\
\text { University of Glasgow and Courtauld } \\
\text { Institute of Art are also embedding the } \\
\text { staff's tweets into the Staff's University } \\
\text { profile page. The Courtauld Institute of } \\
\text { Art provided personal links to blogpost } \\
\text { and Instagram. The section can also } \\
\text { provide links to other associated websites } \\
\text { such as Scopus profile, Google Scholars, } \\
\text { Researchgate and ORCID }\end{array}$ \\
\hline 8 & & Language & $\begin{array}{l}\text { This section indicates if the academic staff } \\
\text { can speak and write in another language. } \\
\text { A section on City University London } \\
\text { allows staff to indicate if they can read, } \\
\text { write, speak, understand spoken and peer } \\
\text { review in another Language. }\end{array}$ \\
\hline 9 & & $\begin{array}{l}\text { Awards and } \\
\text { Recognition }\end{array}$ & $\begin{array}{l}\text { This section is suitable for highlighting } \\
\text { the achievements and recognition of the } \\
\text { academic staff. This section may include } \\
\text { research awards, teaching excellence } \\
\text { award or best paper awards. }\end{array}$ \\
\hline 10 & $\begin{array}{l}\text { Educational } \\
\text { Information }\end{array}$ & Education & $\begin{array}{l}\text { A list of Universities that the academic } \\
\text { staff has attended. This section could also } \\
\text { be incorporated with the Degree and } \\
\text { Qualifications section. University of } \\
\text { University, } \mathrm{PhD}, 1974\end{array}$ \\
\hline 11 & & $\begin{array}{l}\text { Degree and } \\
\text { Qualifications }\end{array}$ & $\begin{array}{l}\text { This section is different from the } \\
\text { Education section. It identified the }\end{array}$ \\
\hline
\end{tabular}




\begin{tabular}{|c|c|c|c|}
\hline & & & $\begin{array}{l}\text { degree and other qualifications by the } \\
\text { academic staff. This section can also } \\
\text { include a qualification from professional } \\
\text { bodies (such as FHEA, CMBE or CMIN) } \\
\text { in addition to University Degree. }\end{array}$ \\
\hline 12 & & Teaching & $\begin{array}{l}\text { The section presents a list (and sometimes } \\
\text { code and summary) of the modules and } \\
\text { course the academic staff teaches. This } \\
\text { information is relevant in showcasing the } \\
\text { expertise of the staff, and it can present a } \\
\text { shared interest for other researchers and } \\
\text { Academic publishers with interest in } \\
\text { those modules. }\end{array}$ \\
\hline 13 & $\begin{array}{l}\text { Research } \\
\text { Information }\end{array}$ & $\begin{array}{l}\text { Publication } \\
\text { Records }\end{array}$ & $\begin{array}{l}\text { This section provides a list of published } \\
\text { output of the academic staff. It should } \\
\text { start with the most recent publication. } \\
\text { For those with a long list, it could be } \\
\text { limited to years (list of publications since } \\
\text { 2000) or to a number (The list of } \\
\text { publications above shows } 50 \text { of } 68 \text { total } \\
\text { publications in University Repository). } \\
\text { This section can be populated through } \\
\text { the University Repository or manually } \\
\text { updated. Universities in the UK (like } \\
\text { Huddersfield and Abertay) uses Pure, a } \\
\text { service from Elsevier which provides } \\
\text { fingerprint (of activities), network, } \\
\text { external collaboration on country level } \\
\text { similar and similar profiles. The } \\
\text { publications should contain a link to the } \\
\text { original piece of work either on the } \\
\text { University repository or publishers' } \\
\text { website. }\end{array}$ \\
\hline 14 & & $\begin{array}{l}\text { Conference } \\
\text { Presentations }\end{array}$ & $\begin{array}{l}\text { This section is different from publication } \\
\text { records as it indicates network and } \\
\text { avenues for engagement and presentation } \\
\text { of work. This information will be } \\
\text { relevant for other staff and } \mathrm{PhD} \text { students }\end{array}$ \\
\hline
\end{tabular}




\begin{tabular}{|c|c|c|}
\hline & & $\begin{array}{l}\text { to know the kind of places to present } \\
\text { their works. }\end{array}$ \\
\hline 15 & $\begin{array}{l}\text { PhD } \\
\text { Supervision }\end{array}$ & $\begin{array}{l}\text { This section of the webpage indicates if } \\
\text { the academic staff is available to supervise } \\
\text { prospective } \mathrm{PhD} \text { students and the areas } \\
\text { that are of interest. This section can also } \\
\text { showcase the number of } \mathrm{PhD} \text { that the } \\
\text { academic staff has successfully supervised } \\
\text { and completed. This section may not be } \\
\text { relevant for Academic Staff who are not } \\
\text { on the research pathway. }\end{array}$ \\
\hline 16 & $\begin{array}{l}\text { Research } \\
\text { Interest }\end{array}$ & $\begin{array}{l}\text { This section is closely linked to PhD } \\
\text { supervision but highlights more of } \\
\text { personal interest of the academic staff. } \\
\text { This section highlights what the } \\
\text { academic staff is presently working on } \\
\text { and willing to explore further. This } \\
\text { section could also be referred to as an area } \\
\text { of expertise. The content of this section } \\
\text { may evolve over years as interest may } \\
\text { change due to exposure and growing or } \\
\text { emerging research areas. }\end{array}$ \\
\hline 17 & $\begin{array}{l}\text { Research } \\
\text { Project }\end{array}$ & $\begin{array}{l}\text { This section indicates what the academic } \\
\text { staff is presently working on and which } \\
\text { may not necessarily be within the } \\
\text { University. It could be a joint project and } \\
\text { collaboration on a multi-disciplinary } \\
\text { level. This section can also include } \\
\text { research grants and other funded projects. } \\
\text { This section can also include patented } \\
\text { ideas/products which emerged from the } \\
\text { research }\end{array}$ \\
\hline 18 & $\begin{array}{l}\text { Research } \\
\text { group }\end{array}$ & $\begin{array}{l}\text { Academic Staff members can be } \\
\text { associated with a department or research } \\
\text { centre. Besides, they may be associated } \\
\text { with research groups, research projects } \\
\text { and teaching groups. }\end{array}$ \\
\hline
\end{tabular}




\begin{tabular}{|c|c|c|c|}
\hline 19 & & $\begin{array}{l}\text { Research } \\
\text { Keywords }\end{array}$ & $\begin{array}{l}\text { These relate closely to research interest, } \\
\text { but instead, they are keywords that } \\
\text { identify the research area of the academic } \\
\text { staff. This could have been generated } \\
\text { from the academic staff's research } \\
\text { activities. }\end{array}$ \\
\hline 20 & & $\begin{array}{l}\text { Research } \\
\text { Statement }\end{array}$ & $\begin{array}{l}\text { This section allows the academic staff to } \\
\text { present a statement that elaborates their } \\
\text { research activities. As seen with } \\
\text { University for the Creative Art, it is not } \\
\text { just about a list of research areas but the } \\
\text { story behind it, the motivations and } \\
\text { experience so far on the research. This } \\
\text { can also be described as Research Vision } \\
\text { as seen with Coventry University }\end{array}$ \\
\hline 21 & $\begin{array}{l}\text { Industry } \\
\text { Information }\end{array}$ & $\begin{array}{l}\text { Knowledge } \\
\text { Exchange }\end{array}$ & $\begin{array}{l}\text { The knowledge exchange is closely } \\
\text { related to the Research Project. This } \\
\text { section is, however, more relevant for } \\
\text { academic staff on enterprises pathway. } \\
\text { This section highlights their activities } \\
\text { which involves developing a range of } \\
\text { knowledge-based interactions between } \\
\text { universities and the wider world, which } \\
\text { result in benefits to the economy and } \\
\text { society. The section can also include } \\
\text { other enterprise interest and activities. } \\
\text { Information about patented } \\
\text { ideas/products which emerged from the } \\
\text { knowledge exchange can also be } \\
\text { included in this section. }\end{array}$ \\
\hline 22 & & $\begin{array}{l}\text { Industry } \\
\text { Experience }\end{array}$ & $\begin{array}{l}\text { This section presents the academic staff's } \\
\text { past experiences outside the University. } \\
\text { This experience may be relevant to } \\
\text { teaching, especially for those who might } \\
\text { have gathered many years of experience } \\
\text { in Industry before coming into academia. } \\
\text { This experience can also indicate } \\
\text { network which may be relevant for }\end{array}$ \\
\hline
\end{tabular}




\begin{tabular}{|c|c|c|c|}
\hline & & & $\begin{array}{l}\text { internship and guest lecturers coming to } \\
\text { the class. This can also be described as a } \\
\text { career overview. }\end{array}$ \\
\hline 23 & & $\begin{array}{l}\text { Installation and } \\
\text { performances }\end{array}$ & $\begin{array}{l}\text { This section will mostly appeal to art } \\
\text { colleges. It allows staff to showcase their } \\
\text { exhibitions and filmography on their } \\
\text { profile. This section is different from the } \\
\text { research output. }\end{array}$ \\
\hline 24 & Engagement & $\begin{array}{l}\text { Membership } \\
\text { and Affiliations }\end{array}$ & $\begin{array}{l}\text { Membership of academy and professional } \\
\text { bodies can be presented in this section. It } \\
\text { can also highlight other forms of } \\
\text { affiliations. The academic staff may also } \\
\text { want to indicate their level of } \\
\text { membership. Designatory letters can also } \\
\text { be used in the Title section. }\end{array}$ \\
\hline 25 & & $\begin{array}{l}\text { Responsibilities } \\
\text { with the } \\
\text { University }\end{array}$ & $\begin{array}{l}\text { Academic staff do have various } \\
\text { responsibilities within the University. } \\
\text { This section can be used to highlight } \\
\text { those responsibilities. It includes course } \\
\text { leadership, program leadership, } \\
\text { mentoring and supporting. This section } \\
\text { can also include previous roles within the } \\
\text { University. }\end{array}$ \\
\hline 26 & & $\begin{array}{l}\text { External } \\
\text { Engagement }\end{array}$ & $\begin{array}{l}\text { This section is closely related to } \\
\text { responsibilities within the University, but } \\
\text { instead, it focuses on engagement outside } \\
\text { the University. This section highlights } \\
\text { external engagements such as Editor of a } \\
\text { journal, Editor of Journal Special Issue, } \\
\text { Editor of Book Chapters, Journal } \\
\text { reviewers, involvement in the } \\
\text { organization of Conferences and external } \\
\text { examination. In some Universities } \\
\text { (Middlesex), this is described as } \\
\text { engagement and impact. }\end{array}$ \\
\hline 27 & & $\begin{array}{l}\text { Media } \\
\text { Appearance }\end{array}$ & $\begin{array}{l}\text { This section presents the academic staff's } \\
\text { media appearance. The section could } \\
\text { provide a link to the news coverage. It }\end{array}$ \\
\hline
\end{tabular}




\begin{tabular}{|l|l|l|}
\hline 1 & \begin{tabular}{l} 
|l \\
\hline 18
\end{tabular} & $\begin{array}{l}\text { could also include an embedded video to } \\
\text { the interview or a sound clip in the case } \\
\text { of a radio interview. In some cases, a } \\
\text { screenshot can also be used to illustrate } \\
\text { the media appearances. In some instances, } \\
\text { the media appearance are divided into } \\
\text { Online, Broadcast (TV, Radio), Print } \\
\text { Press expertise }\end{array}$ \\
$\begin{array}{l}\text { This section allows academic staff to } \\
\text { indicate if they are press-ready. This } \\
\text { expects the staff to have received a form } \\
\text { of training to comment on live matters. } \\
\text { The University' Press Team will mostly } \\
\text { be involved in this arrangement. This } \\
\text { section is different from media } \\
\text { appearance, which may include } \\
\text { newspaper or online coverage of } \\
\text { research. }\end{array}$ \\
\hline
\end{tabular}

\section{Discussion}

The study sought out to establish key themes available for academic staff to showcase and position their academic brand through the University's website. Their profile and strategy for personal branding are limited to the structures available by the University. Though the study found 28 essential elements, it is essential to recognize that not every one of them may be relevant to a staff or a visitor to the page, notwithstanding there is a list of possible sections to consider.

With regards to engagement and the relevance of the sections, it is essential to recognize those who are more likely to visit the profile and engage with the content, necessitating the need always to keep it updated and relevant. First, there are prospective $\mathrm{PhD}$ students who may be looking for a potential supervisor for their research. These students will want to know about the research expertise of the staff, publication record, including the quantity and quality and if the staff is available for supervision and in what areas. Second, there are fellow academic staff who may be looking out for a collaborator on a project. They may want to know what a prospective partner has to offer the team. This could also be evidence of credibility when a partner searches a name and lands on the University's profile. 
Third, there are external stakeholders like funders who may want to know more about the applicant, Recruiting and Headhunting Services that may want to gain an insight into the staff and Marketing Agencies, like publishers who may also find these webpages relevant for their business.

With this understanding, it is vital to recognize whose responsibilities it is to create a webpage and update it. While the University may own the right to the webpage, it will be necessary for new staff to ask for a profile if it has not been created or ordered. The analysis shows that Universities in the UK have the resources to create a web page for their staff, the update and maintenance however seem to be an issue as there were examples of webpages which appears to be empty and gave not been populated with text. Figure 1 below shows a screenshot of a Lecture's profile at Norwich University of the Arts, the page has been created, but there is no content. There could be an argument that this is a page for staff that will be joining soon, but it is important to note that a University staff profile page should not go live if the staff has not started and if the page is empty. The best approach could be to have a staff name with no hyperlink. An empty page does not say well about the University (who creates and operates the webpage) and the Staff (who owns the page). Likewise, if the staff has left the University, their profile should be deleted.
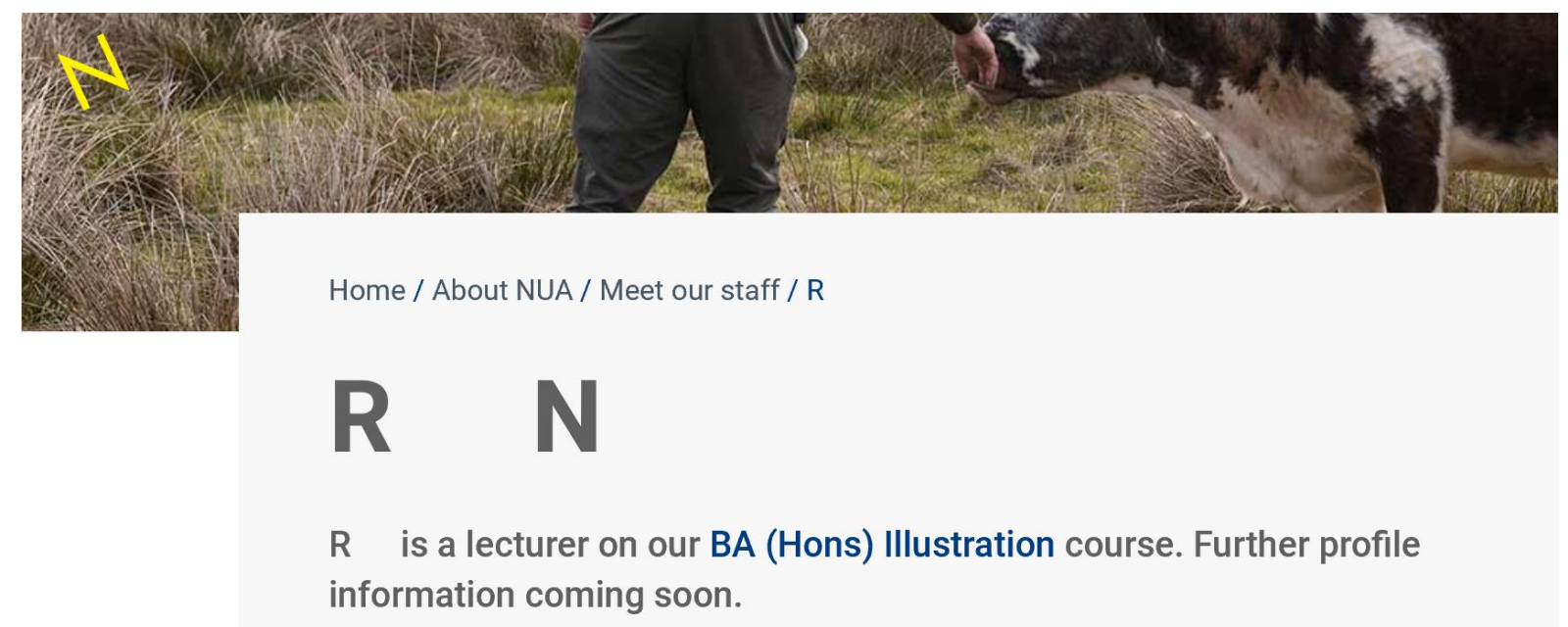

Figure 1: Profile of an Academic Staff at Norwich University of the Arts.

Figure 2 and 3 below show two different profiles from the Courtauld Institute of Art. The first one appears up to date highlighting teaching for 2019/20 session and a book published in 2018 under the title of selected publications. However, the 
second profile is still showing the teaching for 2016/2017 academic session, that is three years behind schedule, and a book that was published in 2008 is still listed as Recent publication. These screenshots were collected in 2020.

\title{
Teaching 2019-20
}

- MA The Sixties: Eccentric, Erotic, Psychotic

- BA1 Foundations Lectures: Sexuality and Subjectivity in Modern and Contemporary Art

\section{PhD Supervision}

Figure 2: Up to date Profile of an Academic Staff at the Courtauld Institute of Art

Teaching 2016-17

- BA3 Special Option: Whistler

- MA History of Art: Victorian Science and Aesthetic Movement Art

\section{PhD Supervision}

\section{Current}

\section{Selected publications}

Books

London: Yale University Press, 2018)

(1)




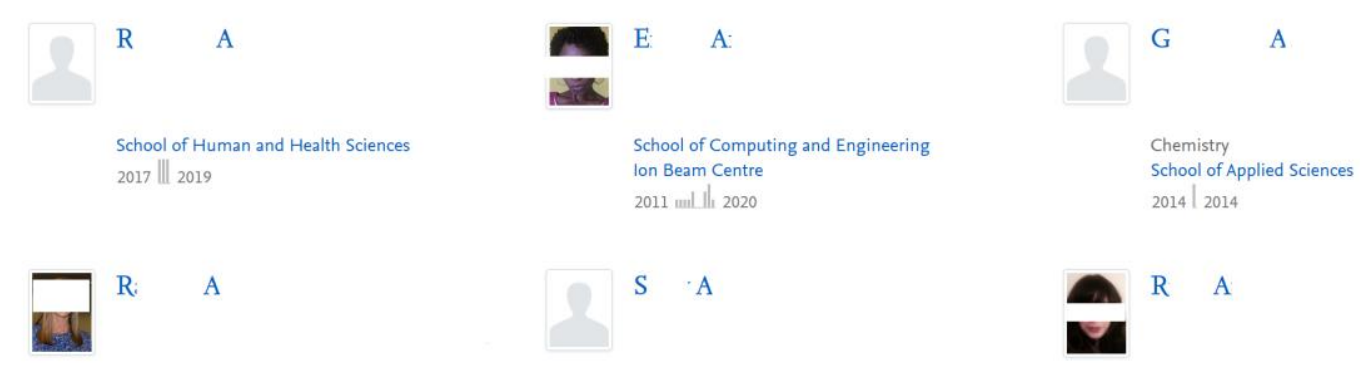

Figure 4: Empty Profile Pictures on University of Huddersfield landing Page

For those that have a webpage, the responsibility is on them to ensure it is updated with the relevant information, including photographs. Universities may not have all the listed 28 themes in Table 1, but those sections provided by the University should be filled. Also, University administrator may have to do an audit, maybe once in a year to check staff profile and advice on those that need to be updated, perhaps having a new photograph, adding a new title or updating the publication records.

Some Universities has simplified the process for staff who may want to edit their profile. Open University (Figure 5) uses Drupal which is an open-source content management system which permits the staff to edit their web profile, and this, however, will still have to be approved before going Live on the University's website. University of Bolton (Figure 6) provided a link which leads to a form for the staff to indicate the changes they want an that can be checked, approved and updated. Nottingham Trent University (Figure 7) uses SquizMatrix which allows staff to set up and edit their profile, and this applies to new staff, who may have to do a self-service and existing staff which needs an update.

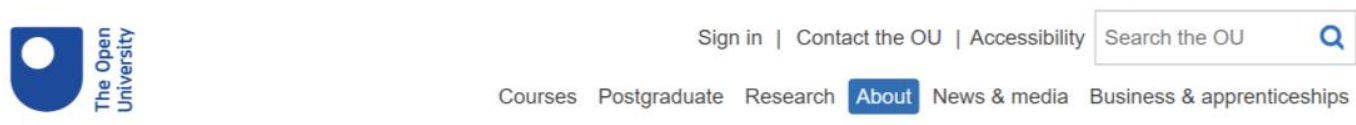

OU people profiles

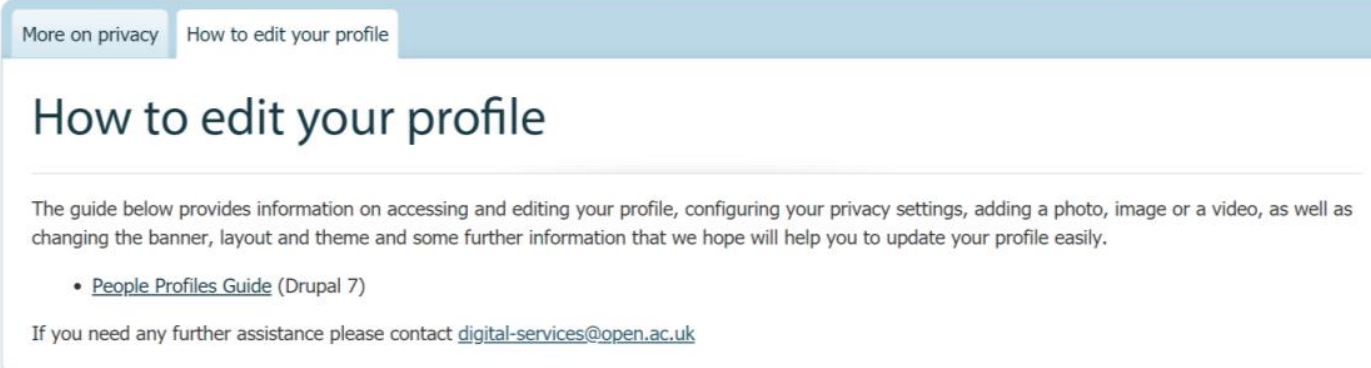

$\uparrow$ Back to top

Figure 5: Screenshot of How to edit profile on The Open University Website 


\title{
Staff Profle
}

Please press the button below to create or amend your staff profile and let us know your ideas for improving functionality. Alternatively, you can email websupport@bolton.ac.uk directly.

STAFF PROFILE

Figure 6: Screenshot of How to edit profile on the University of Bolton Website.

\begin{abstract}
NOTTINGHAM
TRENT UNIVERSITY

Study and courses - Life at NTU - International - About NTU - Research - Business and employers - Jobs -

HOME / DMCS / How-to and guides / Matrix resources
\end{abstract}

\section{Set up and edit your NTU staff profile}

Figure 7: Screenshot of how to set up and edit profile on Nottingham Trent University Website

With regards to updating the websites, it will be worthwhile to mention the Universities which are using Pure for their Staff Profiling. This is a service from Elsevier, which capture data, profile researchers, identify experts \& fundings, analyze \& track research progress, showcase \& collaborate. The system can dynamically visualize and showcase relationships between researchers, grants, projects, outputs, equipment, events, journals, external collaborators and more, through a researcher's graph of relations. Pure also visualizes the relationships between each faculty member and their collaborators, including co-authors of applications or publications as well as partners on projects.

46 Universities, as at the time of writing this report, use Pure. They include Courtauld Institute of Art, Glasgow Caledonian University, Teesside University, University of Ulster, University of Huddersfield and University of Winchester. Downsides of the system, however, is that it maintains the look and layout of Scopus. This layout is different from the layout of the Universities. Secondly, it 
focuses more on research output and having the real feel of an individual's profile which may be beyond research, especially for the Arts School. Courtauld Institute of Art (Figure 8) used the system as a repository for their research while the University of Huddersfield (Figure 9) had it as a landing page for all their staff.

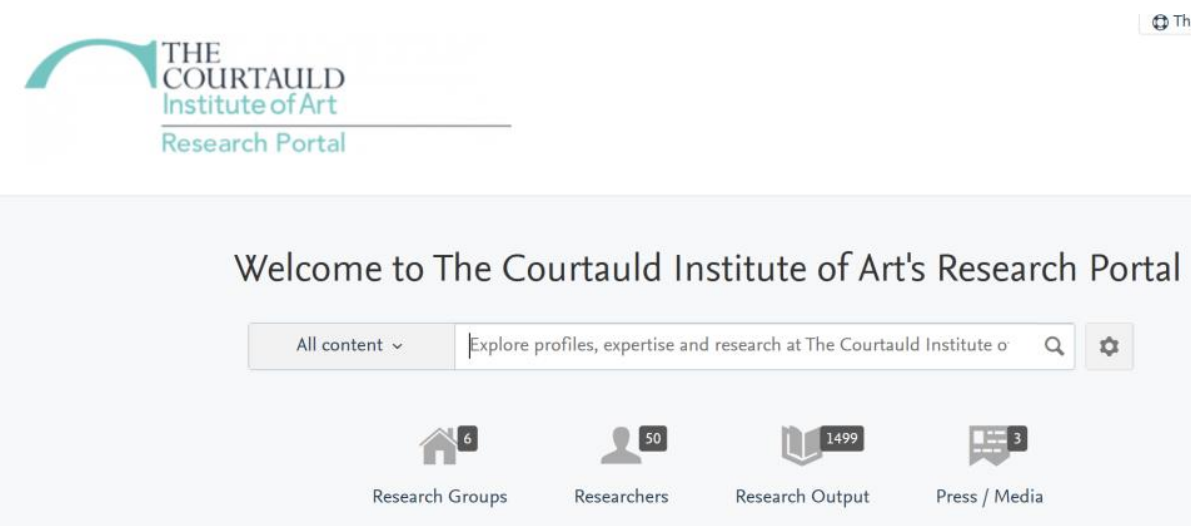

Figure 8: Screenshot of The Courtauld Institute of Art Pure landing page

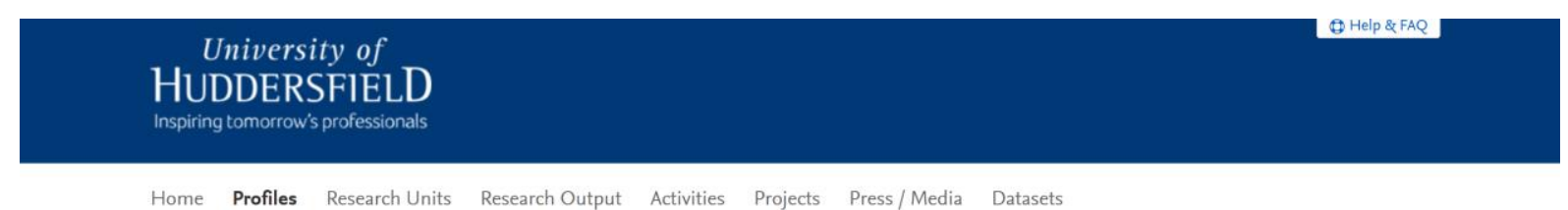

Find Profiles

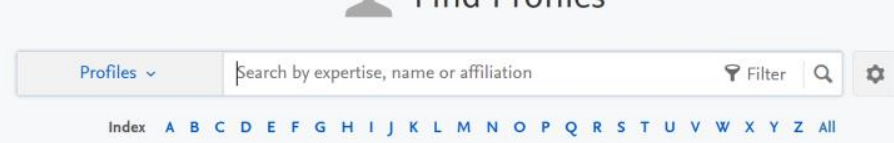

Figure 9: Screenshot of University of Huddersfield Pure landing page

\section{Conclusion}

The analysis of the University profile indicates that UK Universities are putting effort in place to ensure that their staff gets the visibility they need through the University website. There are opportunities for the academic staff to develop and manage their academic brand through this media. While it is recognised that the University still owns the website, it offers huge credibility and can be completed with other media (including social) activities of the academic staff (Farinloye, et al., 2020).

The study identities 28 sub-themes and Five main themes for the University's Academic Staff Profile Webpage. This list, presented in Figure 10 provides a guiding example for Universities who may be considering how to update their staff profile and enhance the academic brands of their staff. Even though personal 
branding is a composite of many parts in one's professional life (Kalia, et al., 2017), university and staff may have to decide which of the section they find relevant to their brand.

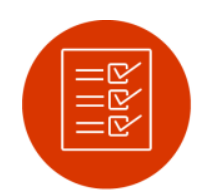

Personal

- Name

- Title

- Position/Status

- Photograph

- Biography

- Contact Details

- Social Media Account

- Language

- Awards and Recognition

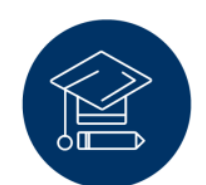

Educational

- Education

- Degree and

- Qualifications

- Teaching

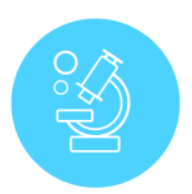

Research

- Publication Records

= Conference Presentations

- PhD Supervision

- Research Interest

- Research Project

- Research Group

- Research Keywords

- Research Statement

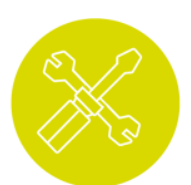

Industry

Knowledge Exchange

Industry Experience

Installation and performances

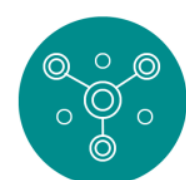

Engagement

- Membership and

Affiliations

- Responsibilities with the

University

- External Engagement

- Media Appearance

- Press expertise

Figure 10: 28 sub-themes and Five main themes for the University's Academic Staff Profile Webpage.

With the profile page in place, academic staff needs to take ownership and responsibility for their academic brand. The profile needs to be updated with recent professionally taken photography, publication records and teaching list should be updated. As some Universities are integrating social media feed into the University profile, staff needs to be aware and more cautious about their online activities as their tweets may be read by those who may not be following them on Twitter. Besides, privacy settings on the part of the University are essential, and perhaps there is some information that the staff may not want to share. In some cases, there is no email address, but a contact form for the staff.

This study contributes to knowledge on academic branding, and it moves beyond social media and websites owned by the staff to another media which is earned by staff but owned by the University. These findings are relevant for University administrators working on creating a platform for academics branding. Also, Universities may want to consider integrating their repository into the staff profile, to save the staff the trouble of manually updating their records. This is an advantage of Pure as it pulls all the research on Scopus and other sources. Academic staff who owns the webpages should take ownership, update it with relevant information. Likewise, to Information Communication Technology (ICT) and the Marketing Team, they are responsible for developing and maintaining the website. Because 
many sections need to fit in into one page to present the staff, the interface design, audit and monitoring are essential.

Although the study was carefully designed and conducted, providing valuable information and insight, this study has limitations which warrant attention and future research. These limitations should be taken into consideration when interpreting the result. This study only focuses on UK universities, and therefore some content may not be applicable in other countries. Besides, websites were accessed at a particular time in January 2020. Changes could have been made to these websites before the publication of this report. Notwithstanding, an insight into the content of UK academic staff profile has been unveiled.

Future studies should endeavour to understand academic staff's perception of their profile page as a brand-building platform, and perhaps if the embedded meaning of the University brands can be transferred to the academic staff brand (McCracken, 1989) through their profile on the website. Also, future research can explore the challenges and concerns around having and maintaining a University profile, perhaps the fact that the staff does not own it and that it can be deleted after leaving the University might be the reason why some will prefer to invest the effort into their social media and website. The study can also be extended into other countries to understand how their academic staffs are positioning themselves through their website.

\section{References}

Farinloye, T., Mogaji, E. \& Kuika, Watat, J., 2020. Social Media for Universities' Strategic Communication. In: E. Mogaji, F. Maringe \& R. E. Hinson, eds. Strategic Marketing of Higher Education in Africa. Abingdon Oxfordshire: Routledge.

Gandini, A., 2016. Digital work: Self-branding and social capital in the freelance knowledge economy. Marketing Theory, 16(1), pp. 123-141.

HESA, 2019. Higher education providers. [Online] Available at: $\quad$ https://www.hesa.ac.uk/support/providers [Accessed 22 2020]. 
Johnson, C. \& Eulanda, S., 2017. Academic Branding: A Case of Six Faculty. s.1., International Textile and Apparel Association (ITAA) Annual Conference Proceedings.

Kalia, V., Patel, A. K., Moriarity, A. K. \& Canon, C. L., 2017. Personal branding: a primer for radiology trainees and radiologists. Journal of the American College of Radiology, 14(7), pp. 971-975.

Mogaji, E., 2016. Marketing strategies of United Kingdom universities during clearing and adjustment. International Journal of Educational Management, 30(4), pp. 493-504.

Mogaji, E., 2019. Strategic Stakeholder Communications on Twitter by UK Universities. Research Agenda Working Papers, 2019(8), pp. 104-119.

Mogaji, E., 2019. The ALARA Model of Information Search on Websites. Research Agenda Working Papers, 2019(6), pp. 82-91.

Mogaji, E., Anyogu, A. \& Wayne, T., 2020. Minding the Gap: An assessment of the quality of course information available on the websites of African Universities. In: E. Mogaji, F. Maringe \& R. E. Hinson, eds. Higher Education Marketing in Africa - Explorations on Student Choice. Switzerland AG: Palgrave Macmillan.

Mogaji, E. \& Yoon, C., 2019. Thematic Analysis of Marketing Messages in UK Universities' Prospectuses. International Journal of Educational Management, 33(7), pp. 1561-1581.

Universities UK, 2020. Members. [Online] Available at: https://www.universitiesuk.ac.uk/about/Pages/memberinstitutions.aspx

[Accessed 22 2020].

Wayne, T., Farinloye, F. \& Mogaji, E., 2020. Analysis of African Universities' Corporate Visual Identities. In: E. Mogaji, F. Maringe \& R. E. Hinson, eds. Strategic Marketing of Higher Education in Africa. Abingdon Oxfordshire: Routledge. 